\title{
İŞ YAŞAMINDA BİREY VE KURUMA YÖNELİK BİR TEHDİT UNSURU: PSÍKOLOJIKK TACIZ (MOBBING)
}

Taner DEMIRKOL ${ }^{1}$

Zeynep ŞAHİ ${ }^{2}$

\section{Özet}

Psikolojik taciz olgusu son yıllarda sıkça duyulan, kurumlardaki verimi ve çalışanlar arasındaki iletişimi, bağl1lı̆̆ çıkan psikolojik taciz kavramı ise çalışan üzerinde kurulan, sistematik olarak ilerleyen, çalışanı ve performansını olumsuz yönde etkileyen; bunun da ötesinde kişide ve iş yerinde hoş olmayan sonuçlar doğuran bir davranış türüdür. İşyerlerinde psikolojik tacizin dünya genelinde yaygın bir olgu olmasıyla beraber ülkemizdeki sıklığının arttığını da söylemek mümkündür. Bu çalışmada, kamu ve özel kurumlarda sıkça yaşanan, örgütlere bir hastalık gibi sızan ve büyük mağduriyetlere, olumsuz sonuçlara sebep olan psikolojik taciz (mobbing) olgusu ve beraberinde getirdikleri irdelenmiş; kamu ve özel kurumlarda tacizin seyri, verileri ve örnekleri incelenmiştir. Çalışmanın amacı psikolojik tacize konu olan olayın analizinin yapılarak, örgütsel ve kurbanların üzerindeki etkilerinin ve çözüm yollarının belirlenmesidir.

Anahtar Kelimeler: Mobbing, psikolojik taciz, iş yaşamı, kurban.

\section{A THREAT TO THE INDIVIDUAL AND ORGANIZATION IN BUSINESS LIFE: PSYCHOLOGICAL HARASSMENT (MOBBING)}

\begin{abstract}
The phenomenon of psychological harassment is a phenomenon that has been frequently heard in recent years and directly affects the efficiency of the institutions and the communication, loyalty, and organizational climate among the employees. The concept of psychological harassment, which we encounter in working life, is established on the employee, systematically progressing, negatively affecting the employee and his performance; Beyond that, it is a type of behavior that causes unpleasant consequences for the person and at work. It is possible to say that although psychological harassment in workplaces is not a common phenomenon worldwide, its frequency in our country has increased. In this study, the phenomenon of psychological harassment (mobbing), which is common in public and private institutions, infiltrates organizations like a disease and causes great victimization and negative consequences, and what it brings with it is examined; The course, data and examples of harassment in public and private institutions were analyzed. The aim of the study is to analyze the incident subject to psychological harassment and to determine the effects and solutions on the organizational and victims.
\end{abstract}

Keywords: Mobbing, psychological harassment, business life, victim.

\footnotetext{
${ }^{1}$ Dr. Öğr. Üyesi, Niğde Ömer Halisdemir Üniversitesi Kamu Yönetimi, eposta: tdemirkol@ ohu.edu.tr, ORCID: 0000-0001-6364-3511

${ }^{2}$ Yüksek Lisans Öğrencisi, Niğde Ömer Halisdemir Üniversitesi, e-posta: zynp43.shn@ gmail.com ORCID: 0000-0002-4889-0327
} 


\section{GİRIŞ̧}

Mevcut çağdaki işyeri ortamlarında çalışanlar bazı zamanlarda fiziksel ve ruhsal sağlıkları için tehdit unsuru olan psikolojik taciz olgusuna maruz kalmaktadırlar. Psikolojik taciz, kamu ve özel sektörde çalışan bireyleri istifaya ve intihara sevk edecek kadar mühim bir şiddet türüdür. $\mathrm{Bu}$ yıldırma politikaları çoğunlukla yoğun ve uzun bir süreç boyunca devam etmekte; kişiyi korkutmak, yıldırmak ve istifa etmesini sağlamak amacıyla gerçekleştirilmektedir.

Günümüzde rekabetin artmasıyla beraber, işyerlerinde insan kaynağına verilen değer de paralel olarak artmaktadır. İşyeri yöneticileri, çalışanların verimliliklerini ve iş hayatının kalitesini negatif yönde etkileyebilecek tüm unsurların ortadan kaldırılması yönünde gayret sarf etmektedirler. Ancak bu hususta sarf edilen tüm gayretlere rağmen örgütlerde insan kaynaklı birçok sorun yaşanabilmektedir. Bu sorunların başında da psikolojik taciz gelmektedir. Psikolojik taciz kavramı, psikolojik yıldırma veya mobbing olarak farklı adlandırmalar ile de karşımıza çıkabilmektedir.

Psikolojik taciz sürecinde kişi, çalışma ortamında yöneticileri ya da çalışma arkadaşları tarafından rahatsız edilmekte; bunun sonucunda işe geç saatte gelme, işten kaytarma, işi bırakma, uzun süreli izin alma gibi örgütsel etkinliği azaltacak davranışlara yönelebilmektedir. Tüm bunların ötesinde, yaşanan psikolojik taciz sürecinde, kişinin sağllğ 1 bütünüyle olumsuz etkilenebilmekte ve kişi kendisini intihara kadar sürüklenebileceği bir sürecin içerisinde bulabilmektedir.

$\mathrm{Bu}$ çalışmada öncelikle psikolojik taciz kavramı kavramsal bir çerçevede incelenerek; süreçleri, aşamaları, türleri ve etkileri gibi çeşitli başlıklar ile bu kavram farklı yönlerden irdelenmeye çalışılmıştır. Çalışma sırasında kamu ve özel sektördeki psikolojik tacize yönelik veriler ile örnekler de incelenmiş, psikolojik tacize yönelik önlemler ve bu hususa yönelik bazı öneriler ise çalışma içerisinde sunulmaya çalışılmıştır.

\section{Kavramsal Çerçevede Psikolojik Taciz}

Psikolojik taciz veya psikolojik yıldırma, İngilizce "mob" kökünden gelen "mobbing" kelimesinin karşılığıdır. İngilizcede mob fiili; rahatsız etmek, saldırmak ve bir yerde toplanmak gibi anlamlar taşımaktadır (Yöney \& Kılınç, 2020: 34-52). Mobbing terimi ilk kez 1980'lerin başında İsveçli psikolog Heinz Leymann tarafından kullanılmıştır. Leymann bu kavramı, bir ya da birden fazla bireyin, farklı bir bireye zarar vermeye çalışan, etik olmayan yollarla sistemli olarak gerçekleştirdiği bir terör olarak ifade etmiştir. Söz konusu kavram, kurumdaki çalışanların performansını, motivasyonunu zedeleyen içtimai bir terim olarak tanımlanmıştır (Şimşek \& Doğan, 2019: 59-67).

Dünya Sağlık Örgütü'nün tanımlamasına göre bu olgu, birey veya birtakım bireylere yönelik, zor kullanarak, beden ve ruh sağlığını yaralayan, etik gelişimini baltalayan davranış bütünü şeklindedir (Akyüz, 2015: 4). Ülkemizde ise Yargıtay kararında belirtildiği üzere "genel olarak "İşyerinde gerçekleşen, sistematik hale gelen, kasıtlı olarak yapılan ve süreklilik gösteren, yıldırma ve işten uzaklaştırma amacı taşıyan, kişinin kişiliğinde, sağlığında ve mesleki 
durumunda zarar doğuran davranışlar" psikolojik taciz (mobbing)' olarak ifade edilmektedir" (Yargitay 9. Hukuk Dairesi, 04.04.2016 T. 2014/37332 E.; 2016/8155 K).

İş yaşamında psikolojik taciz olgusu, ilk defa 1980'lerin başlarında Leymann tarafından kullanılmasıyla birlikte, 1980’li yıllarda popüler hale gelmiştir (Şimşek \& Doğan, 2019: 59-67).

Bir olguyu psikolojik taciz olarak adlandırabilmek için:

1) Devamlılık (tekrar) ve sıkça yaşanması,

2) Güç dengesinin olmamas1,

3) Bilinçli düşmanca tutum,

4) Psikolojik taciz bilinci ve netice olmak üzere bahsi geçen bu dört unsurun varlığ gereklidir (Gedikkaya, 2019: 56).

\section{3. İş Yaşamında Psikolojik Taciz}

İşyerindeki psikolojik taciz eylemleri dünya genelinde tüm çalışanlar için önemli bir sorundur. İş yükünün ve başarının sürekli dikte edildiği, düşük maliyetlerle beraber verimlilik artışı doğrultusundaki politikaların güdüldüğü kurum ya da işletmelerde psikolojik taciz vakaları daha fazla gerçekleşmektedir. Psikolojik taciz, küçük ölçekli işletmelerde, kamuda ve özel sektörün faal olduğu eğitim, hizmetler ve sağlık alanlarında daha fazla yaygınlık göstermektedir (Aşkın \& Aşkın, 2018: 262).

Psikolojik taciz olgusu; mobbing, bezdiri, yıldırma gibi birçok farklı kavramla kullanılmakla birlikte psikolojik şiddet olarak da ele alınabilmektedir. Avrupa Komisyonu, iş yaşamındaki şiddeti bütüncül şekilde ele alarak psikolojik durumu ön planda tutmaktadır. Dünya Sağlık Örgütü de fiziksel ve psikolojik şiddet farkını ifade ederek, psikolojik şiddetin faal olduğunu onaylamaktadır. Böylelikle şiddet, işle alakalı durumlarda çalışan bireylerin güvenliklerine, refah ve sağlıklarına alenen ya da kapalı şekilde meydan okuyan; kötüye kullanma, korku verme ve saldırı olaylarından meydana gelmektedir (Özen, 2007: 4).

Bezdirme olgusunun, iş hayatında maruz kalınan ahlak dışı bir tutum olması gerçeğinden öte, kurban personeller için insan haklarını çiğneyen bir problem olduğunu ifade etmek gerekmektedir. Fakat öte yandan psikolojik taciz, bu tür tutumlarla karşıslaşılan kurum ve işletmeler bakımından da hayli yüksek maliyetlere neden olmaktadır. Sağlık giderlerindeki artışlar, dava giderleri, düşüş gösteren ürün niteliği, çalışan devir hızındaki yükselme, artan devamsızlıklar, müşteri ilişkilerindeki zayıflık, baltalamalar, işe ve örgüte bağlılıkta zayıflık, yaratıcılıkta düşüş, işe ayrılması gereken zamanın muhabbete, iş dışındaki konulara ayrılmasına benzer doğrudan ve dolaylı maliyetlerden bahsedilebilmektedir (Seçkin Halaç \& Güloğlu, 2019: 159).

İş yaşamında psikolojik taciz, çoğunlukla bir zorba kaynaklı ortaya çıkmaktadır. Çalışma arkadaşlarının ya da idarenin bu zorbanın tutumunu iyileştirmedeki eksikliği veya buna dayanması sonucu zorba, güçlenmekle birlikte çevresindeki kişiler de söz konusu bu yıldırmaya ortaklık etme sürecine girmektedirler (Altuntaş, 2010: 3000).

\section{Mevzuatımızda İş Yerinde Psikolojik Taciz}


Anayasa'nın 12. maddesinde belirtildiği üzere herkes, kişiliğine bağl1, dokunulmaz, devredilmez, vazgeçilmez temel hak ve hürriyetlere sahiptir. Kurumda yaşanan psikolojik taciz olgusu da Anayasa'da belirtilen temel hak ve özgürlük kavramlarının suistimali mahiyetindedir. Söz konusu kavramlara değinen bir örnek olarak Anayasa'nın 17. maddesinde herkesin, yaşama, maddi ve manevi varlığını koruma ve geliştirme hakkının olduğu, kimseye işkence ve eziyet yapılamayacağı, kimsenin insan onuruyla bağdaşmayan bir cezaya veya muameleye tabi tutulamayacağı ifade edilmiştir. Kurumda yaşanan psikolojik taciz, insan onuruyla örtüşmediğinden, Anayasa'nın bu hükmünün bariz olarak çiğnendiği görülmektedir (Kasapoğlu Turhan, 2013: 92). Anayasanın yine birtakım maddelerinde bireyin iş yerinde beden ve ruh sağlığı, onuru, güvenliği, huzuruna ilişkin çeşitli hükümler de bulunmaktadır.

19.03.2011 tarihli ve 27879 sayılı Resmi Gazete'de “İşyerlerinde Psikolojik Tacizin (Mobbing) Önlenmesi” başlığ 1 ile yayımlanan 2011/2 sayılı Başbakanlık Genelgesi'nde hem özel sektörde hem de kamu kurum ve kuruluşlarında ortaya çıkan psikolojik taciz ele alınmaktadır (Kasapoğlu Turhan, 2013: 94).

Türk Ceza Kanunu'nda ise psikolojik tacizi ortaya çıkaran tutumlar ile suç türleri arasındaki ilişkinin incelendiği görülmektedir. Psikolojik taciz davranışları içerisine giren suçlar; İntihara Yönlendirme Suçu (TCK m. 84), Kasten Yaralama Suçu (TCK m. 86, 87), Eziyet Suçu (TCK m. 96), Cinsel Saldırı (TCK m. 102) ve Cinsel Taciz Suçu (TCK m. 105), Cebir Kullanma Suçu (TCK m. 108), Kişilerin Huzur ve Sükûnunu Bozma Suçu (TCK m. 123) ve Hakaret Suçu (TCK m. 125) olmak üzere kanun maddesi başlıkları ile ifade edilebilmektedir (Yorulmaz, 2019: 1637).

\section{Psikolojik Tacizin Süreci}

Yaşanan psikolojik taciz olgusunun idrak edilebilmesi için kurumda ortaya çıkan, psikolojik tacize mahal veren tutumların tespit edilmesi önem arz etmektedir. Söz konusu davranışların bir kısmının bütünüyle olumsuz şekilde açıklanmasına rağmen, bir kısmı yalnızca anormal olmayan ya da tarafsız etkileşim tutumları şeklinde gerçekleşebilir. Buna benzer tutumlara, bir defaya mahsus müsamaha gösterilebilir veya bu tutumu gösterenin, o gün adına birtakım olumsuzluklardan etkilendiği için öyle davrandığı farz edilerek hoşgörü gösterilebilir. Fakat söz konusu tutumlar uzun vadede sistematik olarak yinelenirse bilinçli ve kasten uygulanan bir psikolojik tacize dönüşmektedir (Tınaz, 2006: 16). Psikolojik tacizde, zorba ve mağdur arasında orantısız güç vardır. İki kişi nezdinde, bir kişi ile hâlihazırdaki bir küme nezdinde veya kümelerce kişilere uygulanmaktadır. Fiziksel saldırıları ise söz konusu değildir.

Leymann, psikolojik taciz sürecini:

1) Çatışma aşaması,

2) Saldırgan eylem aşaması,

3) Yönetimin devreye girme aşaması,

4) Yanlış yakıştırma ya da tanılarla damgalama aşaması,

5) İşten çıkarılma aşaması olmak üzere beş aşamadan oluşan bir süreç olarak ifade etmektedir (Şimşek \& Doğan, 2019: 61). 


\section{Psikolojik Tacizin Aşamaları}

Psikolojik tacizin gerçekleşme sürecinde birtakım evreler söz konusudur. Taciz, bu evrelerden geçip kendini tamamlayarak ortaya çıkmaktadır.

Psikolojik taciz; rahatsız edici tutumlarla gerçeklemeye başlayan, zamanla sağlığa kadar olumsuz etki gösteren, olay örgüsünün sarmal şekilde ivme kazandığı bir olgu sürecidir. $\mathrm{Bu}$ sürecin ilerleyişi, sürekliliğine müsaade edildiği kadardır. Kurban diye belirlenen kişiye saldırı biçiminde gerçekleşen süreç, en acı neticeye varmadan evvel, kendi içerisinde türlü evrelerde de bitebilir. Psikolojik tacizden sabit bir süreç olarak bahsedilemez, devamlı ilerleyen bir olay örgüsü söz konusudur. Tacizin ilerleme aşamaları, ülkelerin kültürel ayrımlara göre de farklılık taşımaktadır (Çekin, 2014: 8).

Leymann psikolojik tacizi; çatışma, saldırgan eylem, yönetimin devreye girmesi, yanlış yakıştırma veya tanılarla damgalama ve işten ayrılma olmak üzere beş evre sonucunda ortaya çıkan bir süreç olarak ifade etmiştir (Şimşek \& Doğan, 2019: 61).

\section{1. Çatışma Aşaması}

Çatışma evresi, bu aşamaya zemin hazırlayan bir olayla veya mevcut bir çatışmanın kışkırtılmasıyla da gerçekleşebilmektedir. Psikolojik tacizi tetikleyen bu arbedenin ne şekilde gerçekleştiği genellikle tam manasıyla tespit edilememektedir (Tetik, 2010: 83).

\subsection{Saldırgan Eylem Așaması}

Psikolojik tacizin gerçekleşmesinde meydana gelen tutumların her biri, bireyin kurumla bağlantısını kesmek gayesiyle eyleme dökülen saldırı mahiyetindeki tutumlar olarak ifade edilemez. Bununla beraber bezdiri niteliğindeki tutumlar, neredeyse her gün ve uzun vadede saldırgan bir gayeyle devamlılık gösterirse, sıradan günlük diyalog dâhilinde gerçekleşen tutumlar şeklinde ifade edilebilmektedir. Söz konusu tutumlar, bir süre sonra farklı bir biçimde yenilenip; bireyi, grupta yalnızlaştırarak sınırlandırmaya giden düşmanca davranışlar sergilemek yönünde ortaya çıkabilmektedir (Tetik, 2010: 83).

\subsection{Yönetimin Devreye Girmesi Aşaması}

Psikolojik tacizin bu aşamasında yönetimin tutumu önem taşımaktadır. Yönetim; söz konusu taciz olgusunu dikkate almak ya da göz ardı etmek yönünde bir tavır gösterebilmektedir. Eğer bu olguyu dikkate alır da çözüm politikası güderse, bu taciz sona erecektir. Fakat yöneticiler, bu durumu göz ardı etmeye, bu soruna kayıtsız kalmaya karar verirlerse taciz varlığını hala sürdürecektir (Çekin, 2014: 8).

\subsection{Yanlış Yakıştırma veya Tanılarla Damgalama Aşaması}

Psikolojik taciz mağduriyeti yaşayan birey, maruz kaldığı sorunları çözebilmek adına tıbbi desteğe başvurmak isteyebilmektedir. Örgütteki diğer bireylerin, psikolojik tacize maruz kalan bireyin tıbbi destek sürecini haber almalarının ardından mağdura dair doğruluğu olmayan söylemleri ürettikleri görülebilmektedir. Mağduriyet yaşayan birey haksız yere; ruh hastası, güç insan ya da akli dengesi yerinde olmayan kişilik şeklindeki çirkin söylemler ile yaftalanabilir. Bu tutum karşısında, yönetimin yargısının yanı sıra psikolojik taciz kavramına dair yeterli bilgi 
düzeyi olmayan sağlık çalışanlarının yanlış tanıları da söz konusu olunca, tacizde negatif döngü hızlanmaktadır. Bireyin başvurduğu tıbbi destekle, yeniden iş hayatına dönmesi beklenmesine rağmen genellikle uzun süreli hastalık izinleriyle iş yaşamına ilişkin bağlarını koparma seçeneği uygulanmaktadır (Şimşek \& Doğan, 2019: 62).

\section{5. İşten Ayrılma Aşaması}

Bu aşama psikolojik tacizin son evresidir. Çoğunlukla işi bırakma, işten kovulma, istifa etme ya da istifaya sevk etme, vaktinden önce emekliliğe zorlanma veya farklı travmatik durumlar ile neticelenebilmektedir (Çekin, 2014: 8).

\section{7. İş Yaşamında Meydana Gelen Psikolojik Taciz Türleri}

\subsection{Dikey (Hiyerarşik) Psikolojik Taciz}

Bu psikolojik taciz türü, en sık maruz kalınan psikolojik taciz çeşididir. Özellikle otokratik idare mantığının özümsendiği kurum ve işletmelerde ortaya çıkmaktadır. Yönetimdeki üstlerin, çalışanları psikolojik tacize maruz bırakmalarının sebepleri içinde; bireysel çatışmalar, öznel peşin hükümler, başarı gösteren astların ileride kendilerine rakip olabileceği yönünde fikirler ya da mağlubiyet gösteren grup üyelerinin tasfiyesi gibi hususlar bulunmaktadır. Örgüt yapısı ile psikolojik tacizin yönü arasında bağlantı kurulduğunda, hiyerarşik düzenlerde disiplin ve kuvvet kullanımı yaygın olduğundan genellikle dikey psikolojik tacizin yaşandığı ifade edilebilir. Dikey psikolojik taciz; bir üst bünyesinde, türlü nedenlere bağlı olarak, doğrudan mağdura karşı, hayli düşmanca ve sınırlayıcı tutumların sergilenmesidir. Bir üst ya da idarecinin mesleki görevinin getirdiği mevkiden yararlanarak gücünü fazlaca kullanmasıyla bağlılaşım gösterecek tutumlarla astlarını maruz bıraktığı psikolojik tacize işaret etmektedir (Şimşek \& Doğan, 2019: 62).

Dikey psikolojik taciz, yalnızca yukardan aşağıya değil, aşağıdan yukarıya doğru da gerçekleşebilecek çift taraflı psikolojik taciz olgusunu veya düşmanca tavırları ortaya koymaktadır. Astlar, üstlerine ya ferdi şekilde veya toplu şekilde yıldırma gayretinde bulunabilmekte ve üstlerine tahakküm uygulayabilmektedirler (Şahin, 2015: 495).

\subsection{Yatay Psikolojik Taciz}

Yatay psikolojik taciz ise fonksiyonel bağlılaşım içinde bulunan aynı düzeyler arasında ortaya çıkan bir psikolojik taciz çeşididir (Yöney \& Kılınç, 2020: 37). Yatay psikolojik taciz, eşit konumdaki personellerin arasında gerçekleşen yıldırma olayına işaret etmektedir. Eşit konumdaki personelin daha fazla başarı göstermesi, diğer çalışanlarca desteklenmesi, saygı görmesi gibi sebeplerle söz konusu yıldırma türü gerçekleşebilmektedir (Şahin, 2015: 496).

Kurumlarda üstlerden astlara veya astlardan üstlere yönelik taciz, dikey psikolojik taciz şeklinde isimlendirilmekteyken aynı konumda bulunanlar arasındaki yıldırma ise yatay psikolojik taciz şeklinde isimlendirilmektedir. Yatay psikolojik taciz, aralarında işlevsel bağlantılar olan bireylerde ortaya çıkan taciz türü olmakla beraber kıskançlık ve hasetlik yönündeki sebeplerden de kaynaklanabilmektedir (Şimşek \& Doğan, 2019: 62).

Yatay psikolojik tacizde iş yeri idaresinin taraf olması önemli bir eşik olmakla beraber, bu yanlış tutum bir örgüt politikası ve anlayışına dönüşebilmektedir. Mağdur, yalnızca aynı kademedekilerle değil idaredeki yöneticilerle de mücadele etmek durumunda kalabilecektir. 
Sonuç olarak bu durum, mağduriyet yaşayan birey örgütten uzaklaşmasına sebep olmakla birlikte bireyi örgütsel çalışma ve faaliyetlere katılmamaya da sevk edebilmektedir.

Dikey psikolojik taciz çoğunlukla alenen ve bariz bir psikolojik taciz türü iken; yatay psikolojik taciz, dikey psikolojik taciz gibi net ve görünür olduğu söylenemez. Denk kademede olanlar çoğunlukla, gösterdikleri psikolojik taciz tutumunu göz ardı ederek, bunu yaptıklarına ikna olmamaktadırlar. Tersine bu tutumu, çalışanın yararı adına, onu ikaz etme mahiyetinde yaptıklarını ifade etmektedirler. Söz konusu tutumun temelinde, güdülenmenin kurumsal verimliliği yükseltmek yönünde bir gaye bulunduğunu dile getirerek, bu yıldırma politikasını doğru ve gerekli bir temellendirme ile açıklamaktadırlar (Çekin, 2014: 9).

\section{Psikolojik Tacizi Uygulayanlar}

Psikolojik taciz uygulayıcıları çoğunlukla örgüt içinde amir pozisyonunda olan kişilerdir. Psikolojik taciz uygulayanlar, kendi eksikliklerini gidermek için, psikolojik şiddete başvurmaktadırlar. Kendi statüleri adına duydukları korku ve güvensizlik, onları başka bir çalışana dair psikolojik taciz uygulamaya sevk etmektedir. Bu perspektiften zorba, kesin olarak bir kişilik sorunu yaşamaktadır. Bireyin sosyalleşme güdüsü, topluluk aidiyetiyle yaşama isteği ve ihtiyacı; onu, bir grubu kabul edip benimserken, diğer grubu da dışlamaya itmekte ve mücadele de bu noktada başlamaktadır (Karakaş \& Okanl1, 2013: 568). Zorbanın davranış1 çoğu zaman çeşitli kişilik bozukluğu kavramlarıyla tanımlanmaktadır. Psikolojik tacizdeki zorba; önyargıları sebebiyle bağnaz, güç göstermeye ihtiyaç duyan, saldırgan, empati kurmaktan uzak, kurbanın acı çekmesinden zevk duyan kimseler olarak ifade edilmektedir. Zorba, kurumda özsaygı ve konum edinmek ya da örgütsel bir değişim söz konusu olduğunda, mevcut durumunun muhafazası adına, kendi yetenek ve becerilerini kullanması gerekirken, hedef belirlediği kişileri taciz ederek, benliğinin bilinmeyenlerini ön plana taşımaktadır. Kurbanın kişiliğine ve mesleki onuruna yönelttiği lekeleyici ve aşağılayıcı davranışlarla kendisinin yüceldiğini; böylelikle yerini sağlamlaştırarak gücünü arttırdığını düşünmektedir. Esasen tutumlarının çoğu aşırı kontrolcü, korkak, nevrotik ve yönetim açlığı gibi özelliklerle açıklanabilir. Yaşadığı güvensizlik ve korku hissi, kıskançlığını, düşmanca davranışlarını pekiştirebilmektedir (Özen, 2007: 14).

\section{Psikolojik Tacizin Ortaya Çıkmasındaki Nedenler}

İşyerinde yaşanan psikolojik taciz olgusu yalnızca bir nedenle ifade edilemeyecek kadar geniş ve anlaş1lması güç bir süreçtir (Cevher \& Öztürk, 2015: 864). İş yaşamında psikolojik tacize sebebiyet veren bireysel ve kurumsal birden fazla unsur söz konusudur (Öztürk \& Şahbudak, 2017: 205). Söz konusu tacizin tek taraflı ya da sürekli sabit bir yönden geldiği söylenemez. Tacizin ortaya çıkışında ve süreç içindeki ilerleyişinde birey/bireyler ve yönetici konumunda olanlar; psikolojik taciz tehdidiyle karşı karşıya kalma gerçeği yönünde birer adaydır.

İşyerinde karşılaşılan saldırganlığın en önemli iki sebebi, benlik değerini muhafaza etme düşüncesiyle kişisel misilleme ve sosyal beceri noksanlıkları olarak belirtilmiştir. Bireyin dengeli, kararlı bir içsel değerlendirmeye yapabilmesi, zorbalığın ivmesini ve kendisini yavaşlatmaktadır. Fakat bireyin benliğine duyduğu değer, dışarıdaki insanların değerlendirmesiyle gerçekleşiyorsa, zorbacılık, çatışmalar ve psikolojik taciz kendini göstermeye başlamaktadır (İdiğ Çamuroğlu \& Minibas Poussard, 2017: 56-57). 
İş yaşamında psikolojik tacize ortam hazırlayan örgütsel nedenlerse güçlü hiyerarşi mekanizması, rekabet, iş güvenliğinin olmaması, rol çekişmeleri ve belirsizliğinin gerçekleşmesi, personel ile idarecilerin birbirine entegre olamaması, örgüt içindeki stres, örgütteki liderlik türü ve negatif seyreden iklim, çalışma şartlarının iyi olmaması, personel arasında grup baskısının olması, örgüt içi iletişimin zayıflı̆̆ı, idarenin kurumdaki çatışmaları engellemekte güçsüz kalması faktörleriyle belirtilmektedir (Öztürk \& Şahbudak, 2017: 205).

\section{Psikolojik Tacizin Etkileri}

\subsection{Psikolojik Tacizin Mağdur Üzerindeki Etkileri}

Psikolojik taciz kavramının mağdura olan etkileri ilk etapta psikolojik olmak üzere fiziksel, sosyal ve ekonomik açıdan da ifade edilmelidir. Yıldırma eylemlerinin bireyi yalnızlığa sürüklemesi, özgüveni azaltması, stresi arttırması gibi sonuçlar, mağdurun psikolojisini bozmakta ve onu hasta edebilmektedir. Psikolojide ortaya çıkan sorunlar "psikosomatik" olarak ortaya çıkan fiziksel rahatsızlıklara da dönüşebilmektedir.

Yapılan bilimsel çalışmalar, psikolojik taciz kavramının en çok psikolojik taciz kurbanlarını olumsuz etkilediğini saptamıştır. Psikolojik taciz ile karşı karşıya olma seviyesi yükseldikçe, ortaya çıkan olumsuz etki ve sonuçlar da o denli artış göstermektedir. Diğer bir deyişle bilerek ve düzenli şekilde yinelenen psikolojik tacizin muhtemel tesiri çalışanda zamanla beliren olumsuz ve kötü sonuçlar bütünü şeklinde kendini göstermektedir. Yaşanan bu evreyle birlikte kurban olarak algılanan çalışanların özgüven ve özsaygıları da kaybolmaya yüz tutacaktır (Çekin, 2014: 15).

Psikolojik tacizle karşı karşıya olan çalışanlar, bu mağduriyetin etkisi olarak, çoğunlukla hislerini gizlemeleri sebebiyle obsesif, öfkeli yahut agresif davranabilmektedirler. Bunun yanı sıra nadiren ortaya çıkan, daha yoğun derecelerde psikolojik tacizle mücadele etmek zorunluluğu yaşamış çalışanlarda bir nevi "travma sonrası stres bozukluğu” görülebilmektedir (Çekin, 2014: $15)$.

\subsection{Psikolojik Tacizin Örgüt Üzerindeki Etkileri}

Psikolojik taciz olgusu kısa bir zaman diliminde örgütün bütün hücrelerinde negatif sonuçlara sebep olmaktadır. Kurum kültürü ve iklimini bozmakla kalmayıp, iş yerinin itibarına da zarar vermektedir. Çalışma uyumunun, ruhsal gücün ve itimat parçalarından oluşan bütünün yok olmasına sebebiyet vermektedir. Çalışma şartları ve görev tanımlarıyla ilgili yakınmalar artmaya başlamaktadır. Kurumdaki adaletsiz ve hoş olmayan davranışlar tüm çalışanların anlayabileceği bir şekil almaktadır. Bu huzursuz ortamdan ayrı kalma düşüncesi, izin talebini de artırmaktadır. İşgücü devrinin yükselmesi ve erken emeklilik isteğinde de artış söz konusu olmaktadır. Disiplin soruşturmaları sıkça işlenme göstermeye başlamakta ve kurumda kaygı ve korku havası kendini göstermektedir. Personeller lüzumsuz yere, iş ortamının değiştirileceği ve soruşturmadan geçeceğine yönelik alenen yahut üstü örülü tehdit mesajlarına maruz kalmaktadır. Kurum ilkeleri sürekli yenilenmekte, ayrıca bireye yönelik yeni ilkeler oluşturulmaya başlanmaktadır. Haberleşme faaliyetleri kurban olarak belirlenen çalışanların dışlanmasıyla şekillenir. İş yerinde olup bitenden, toplantı ve bu tür faaliyetler haber verilmez, yokmuş gibi davranılır (Yücetürk, 2012: 52). 
Kurumda yaşanan psikolojik taciz davranışlarının, kurban seçilen bireyin ardından en fazla örgütü ve örgüt kültürüne olumsuz olarak yansıdığı ifade edilebilmektedir. Psikolojik tacizin kurumlarda ne tür neticeler oluşturduğuna dair kati hükümlerden bahsedilmesi doğru olmamakla birlikte üretim giderlerinin artması, personel devir hızının yükselmesi, kurumda artan huzursuzluk ve stres; personellerin hissettiği bask1, yorgunluk ve bezginliğe sebebiyet verebilmektedir. Tüm bunların neticesinde personellerin başarı grafiğinde düşüşler görülebilmekte, devamsızlıklarda artışlar ortaya çıkabilmektedir. Yaşanan psikolojik taciz, yönetime olan itimadı zedelemekte ve birim ile çalışanlar arasında koordinasyon sorunlarının başlamasına neden olabilmektedir. Çalışanın iş tatmini, kariyer planları da olumsuz etkilenecek ve işe bağlılığında düşüş yaşanacaktır. (Çekin, 2014: 15).

\section{Kamu ve Özel Sektörde Psikolojik Tacize Dair Bazı Veriler}

Çalışma ve Sosyal Güvenlik Bakanlığı'nın 170 numaralı hattına 2011 ile 2016 yılları arasında bilgilenmek ve psikolojik destek istemek için 38 bin 262 kişi başvuru yapmıştır. Bu kişilerin 31 bin 113'ü özel sektörde çalışmaktadır. Sektörlerin genel tablosundaki verilere bakıldığında sanayi sektörü birinci, mağaza-restoran ve market sektörü ikinci, hizmet sektörü ise üçüncü sırada gelmektedir. Kamudaki en çok aramalarda sağlık sektörü birinci sırada yer alırken; özelde en çok arama sanayi sektöründe olmakla birlikte mağaza-restoran ve market sektörü ikinci, hizmet üçüncü, özel sağlık hizmetleri dördüncü, turizm sektörü ise beşinci sırada yer almaktadır (Özçelik Sözer, 2017).

ALO 170'e iletilen şikâyetler doğrultusunda kamu alanında öğretmen ve üniversite personelinin sorun yaşadığı da saptanmıştır. Bilhassa Milli Eğitim Bakanlığı ile üniversitelerden ulaşan şikâyetler çoğunluklu olarak ön planda yer almaktadır. Üniversitelerde bu tarz tutumların görülmesi gerçekten de yadırganacak türdendir. Fakat bu durum, psikolojik tacizin eğitim seviyesiyle direkt bağlantılı olmadığını da ortaya koymaktadır. İstatiksel verilerin sonuçlarına göre özel sektörün sanayi alanında, diğer alanlara nazaran daha büyük yoğunlukta psikolojik taciz yaşandığı görülmüş̧ür (Aslım, 2017).

\section{Psikolojik Tacize Yönelik Önlemler}

Psikolojik taciz ile mücadelede en önemli nokta, mağdurun farkındalığı kadar yönetici, diğer personeller ve en son sosyal bütünlük olarak soruna dair farkındalığın eşit önem derecesinde oluşması ve şekillenmesidir. Bu alana ilişkin tüm çalışanlar, işyerindeki psikolojik tacize son vermek adına dirsek temasına geçerek gayret gösterebilmelidir. Fakat çaba gösterilmesi için, ilk olarak, o konunun tanımlanması gerekmektedir. Bu hususta, konuya ilişkin olarak kamuoyunun bilinçlendirilmesi ve duyarlılığının artırılması önem arz etmektedir (Tetik, 2010: 86).

Çalışanların, öncelikle psikolojik tacize karşı bireysel olarak mücadele edebilmeleri için ilk adımda, haklarını bilicinde olmalı ve haklarını aramaktan çekinmemeleri gerekmektedir. Kişi öncelikle mesleki vasıflarını geliştirerek, kendine özgüven oluşturmalıdır. Bu anlamda kişi kendisini "kurban" algısından kurtarmalı, kontrollü ve emin adımlarla ilerleyerek, önündeki tüm alternatifleri değerlendirmelidir (Mizrahi, 2013: 448).

Psikolojik taciz konusunda yine çözüm önerisi olarak, her kurum kendine ait, bu yıldırmaya karşı çözüm üretebilecek birimini kurmalı ve kurumun saydam, hakkaniyetli bir şekilde işlev 
kazanması için uygun bir ortam hazırlamalıdır. Personellerin görev sınırlarını net olarak belirlenmeli ve personeller görev tanımına göre çalışmalıdır. Bu mücadelede örgütsel diyalogu geliştirmek de sürece iyileştirici bir etki sunmaktadır. Bütün kurumlar örgüt kültürü ve yapısını geliştirmeye gayret etmelidir. Tüm işyerlerinde psikolojik taciz konusuna dair bilinç oluşturulmalıdır (Erdem, 2014: 617-628).

Psikolojik tacizle mücadelede bireysel hareket etmenin belli bir noktadan sonra yetersiz kalacağı düşünülebilir. Psikolojik tacize uğrayan kişi gerek manevi gerekse hukuki açıdan destek almak isteyebilir. Tüm bu nedenlerle, psikolojik taciz sürecinde kolektif yani kurumsal mücadele oldukça önemlidir. Kurumsal mücadele için çeşitli alanlarda birçok sivil toplum örgütü bulunmakla birlikte böyle bir durumla karşılaşan kişiler psikolojik tacize dair kurulan dernekler, insan hakları örgütleri ve meslek örgütlerinden yardım alabilirler. Örneğin ülkemizde faaliyetlerini sürdüren Mobbing ile Mücadele Derneği "Mağdur Başvuru Formu" ile kendisine başvuruda bulunan psikolojik taciz mağdurlarına bireysel destek vermekte ve mağdurların kurumsal bir mücadele içerisinde bulunmalarına imkan sağlamaktadır (Bireysel destek, Mobing ile Mücadele Derneği, t.y.).

Çeşitli sivil toplum örgütleri ve bu örgütlerde görev alan kişiler, psikolojik tacize dair farkındalığın arttırılması ve mağdurların mücadelede izlemesi gereken yollara yönelik yayınlar ve tavsiyeler ile çalışanları bilgilendirmeye gayret göstermektedirler. Mobbing ile Mücadele Derneği Başkanı Prof. Dr. Vedat Bulut da psikolojik tacize maruz kalanlar için çeşitli tavsiyelerde bulunmuştur. Bu tavsiyeler şu şekilde özetlenebilir:

-Öncelikle psikolojik tacize dair yaşanan tüm süreçlerin bütün detayları ile yazıldığı bir günlük tutulmalıdır,

-Günlükte çatışmanın başlangıcı ve devamında yaşanan olaylar tarihleriyle birlikte kaydedilmelidir,

-Yaşanan olaylarda yer alan ve şahit olan kişiler günlükte yer almalıdır,

-Soruşturma ve dava süreçleri yaşandı ise bu süreçler ile ilgili tüm bilgiler de günlüğe kaydedilmelidir,

-Tüm yazışmalar ve elektronik postalar saklanmalıdır,

-Alo 170 Çalışma ve Sosyal Güvenlik İletişim Merkezi aranarak psikolojik tacize dair süreç resmi olarak kayıt altına alınmalıdır,

-Süreç içerisinde ortaya çıkabilecek psikosomatik hastalıklar nedeniyle mümkün ise doktor raporu alınmalıdır,

-Psikolojik tacizde bulunan kişi uyarılmalı ve psikolojik tacizi durdurması istenmelidir,

-Yapılan uyarıya rağmen psikolojik tacizde bulunan kişiden olumlu bir yanıt alınamıyor ise psikolojik tacizde bulunan kişinin bir üstündeki amire gidilmelidir,

-Mahkeme sürecinde kanaat oluşmasına sebep olduğundan başka hiçbir şekilde ispatı mümkün olmayan durumlarda sadece cep telefonu kullanılarak olay sırasında ses ve görüntü kaydı alınabilir, 
-Psikolojik taciz mağduru Mobing ile Mücadele Derneği ile iletişime geçebilir (Özçelik Sözer, 2017).

Psikolojik tacize karşı bireysel anlamda alınacak en etkili önlem, çalışanların bu hususta sahip oldukları yasal hakları bilmeleridir. Gerek kamuda gerekse özel sektörde çalışanların, psikolojik tacize dair yasal haklarını tam manası ile bilmeleri ve böyle bir durumla karşılaştıklarında hangi yasal yollara başvurabileceklerini önceden öğrenmeleri oldukça önemlidir. Kamu sektöründe çalışanlar için psikolojik tacize dair alabilecekleri hukuki önlemlerden bazıları şöyle sıralanabilir:

-İdareye şikayet başvurusunda bulunulabilir (Kasapoğlu Turhan, 2013: 99),

-ALO 170 Çalışma ve Sosyal Güvenlik İletişim Merkezi üzerinden şikayette bulunulabilir (Şikayet ve başvuru yolları, Mobbing ile Mücadele Derneği, t.y.),

-Cumhurbaşkanlığı İletişim Merkezi (CIMER) üzerinden şikayette bulunulabilir (Şikayet ve başvuru yolları, Mobbing ile Mücadele Derneği, t.y.),

-Türkiye İnsan Hakları ve Eşitlik Kurumu'na başvurulabilir (Şikayet ve başvuru yolları, Mobbing ile Mücadele Derneği, t.y.),

-Anayasa Mahkemesi'ne bireysel başvuruda bulunulabilir (Şikayet ve başvuru yolları, Mobbing ile Mücadele Derneği, t.y.),

-Kamu Denetçiliği Kurumu'na başvurulabilir (Kasapoğlu Turhan, 2013: 106),

-Kamu Görevlileri Etik Kurulu'na başvurulabilir (Kasapoğlu Turhan, 2013: 108),

-İdareye karşı tam yargı davası açılarak tazminat talep edilebilir (Maraş Büken, 2019),

-Cumhuriyet Başsavcıllı̆̆ı'na suç duyurusunda bulunulabilir (Kasapoğlu Turhan, 2013: 124),

-Çalışmaktan Kaçınma Hakkı kullanılabilir (Kasapoğlu Turhan, 2013: 122).

Özel sektör çalışanları için de kamu sektöründe çalışanlarda olduğu gibi psikolojik tacize dair alabilecekleri bazı hukuki önlemler bulunmaktadır. Bu hukuki önlemlerden bazıları şöyle sıralanabilir:

-ALO 170 Çalışma ve Sosyal Güvenlik İletişim Merkezi üzerinden şikayette bulunulabilir (Şikayet ve başvuru yolları, Mobbing ile Mücadele Derneği, t.y.),

-Cumhurbaşkanlığı İletişim Merkezi (CIMER) üzerinden şikayette bulunulabilir (Şikayet ve başvuru yolları, Mobbing ile Mücadele Derneği, t.y.),

-Türkiye İnsan Hakları ve Eşitlik Kurumu'na başvurulabilir (Şikayet ve başvuru yolları, Mobbing ile Mücadele Derneği, t.y.),

-Anayasa Mahkemesi'ne bireysel başvuruda bulunulabilir (Şikayet ve başvuru yolları, Mobbing ile Mücadele Derneği, t.y.),

-Psikolojik tacizin durdurulması, önlenmesi ve tespitine yönelik davalar açılabilir (Hüseyinli \& Aslan Atabay, 2017: 623), 


\section{-Cumhuriyet Savcılığı'na şikâyette bulunulabilir (Yapışlar, t.y.)}

-İş akdi her ne sebeple feshedilirse edilsin kıdem ve ihbar tazminatını alabilir (Hüseyinli \& Aslan Atabay, 2017: 627),

-İş akdi feshedilen işçi işe iade hakkını kullanabilir (Hüseyinli \& Aslan Atabay, 2017: 627),

-Çalışmaktan Kaçınma Hakkı kullanılabilir (Hüseyinli \& Aslan Atabay, 2017: 628).

\section{Psikolojik Tacize Dair Vaka Örnekleri}

Gerek basında çıkan haberlerde gerekse yargı organlarında açılan davalarda psikolojik tacize dair birçok vaka örneğine rastlamak mümkündür. Bu vaka örnekleri hem kamu sektöründe hem de özel sektörde görülebilmektedir. Psikolojik tacize maruz kalanların yargı organlarında açmış oldukları davalar, psikolojik tacize dair yaşanılan tüm sürecin resmi olarak kayıt altına alınmasını sağladığından dolayı oldukça önem arz etmektedir.

\subsection{Kamu Sektöründe Psikolojik Tacize Dair Vaka Örneği}

Sakarya 1. İdare Mahkemesi’nde görülen bir davada, psikolojik tacize maruz kaldığını iddia eden ve kamuya ait bir hastanede başhemşire olarak çalışan davacı manevi tazminat talebinde bulunmuştur. Dava sonucunda mahkeme "kişilik hakları ve manevi bütünlügünün zarara uğratıldığına" karar vermiş ve basında "başhemşire mobbing davasını kazandı" başlı̆̆ ile bu dava yer almıştır (Başhemşire mobbing davasını kazandı, Cnn Türk, 23 Mart 2011).

Dava özeti incelendiğinde mağdur olan davacının Mart 2009 tarihinden itibaren altı adet soruşturma geçirdiği, soruşturmaların neticesinde dört adet disiplin cezası aldığ 1 ve bununla yetinilmeyip geçici bir görevlendirme ile isteği olmadan çalıştı̆̆ hastanenin dışındaki bir hastanede görevlendirildiği belirtilmektedir (Sakarya 1. İdare Mahkemesi, 17.01.2011 T. 2010/474 E.; 2011/187 K). Dava özetinde belirtilen hususlar göz önüne alındığında örnek vakadaki mağdurun, bu çalışmada daha önce bahsedilen ve en sık yaşanılan psikolojik taciz çeşitlerinden birisi olan dikey (hiyerarşik) psikolojik tacize maruz kaldığı görülmektedir.

Savunmanın özeti incelendiğinde davacıya iki ayrı başhekimin disiplin cezası verdiği, cezayı veren amirlerin davacının kişilik haklarına karşı bir tutum içerisinde olma ihtimallerinin olmadığı, verilen cezaların hukuka uygun olduğu, davacının ruhsal sorunlarının olduğu ve depresyon tanısı bulunan raporlara sahip olduğu, idari yargıda mobbing uygulaması olarak dava açılamayacağı hususları savunulmuştur (Sakarya 1. İdare Mahkemesi, 17.01.2011 T. 2010/474 E.; 2011/187 K). Özellikle psikolojik tacize yönelik idari yargıda dava açılamayacağına dair ileri sürülen savunmayı biraz irdelemek gerekmektedir. Psikolojik taciz kapsamındaki davranışlardan dolayı oluşan zararların tazmininde kamu görevlisinin kendisi yani gerçek kişi sorumlu olmalı ve gerçek kişilere idari yargıda dava açılamayacağı için adli yargıda tazminat davası açılmalıdır (Kasapoğlu Turhan, 2013: 118). Ancak bu vakada, mahkemenin karar metni incelendiğinde görüldüğü üzere, hastane idaresinin de bazı sorumluluklarını tam olarak yerine getirmediği anlaşılmaktadır. İdarenin hizmet kusuru nedeniyle sorumluluğunun söz konusu olduğu durumlarda ve hizmet kusuru ile kişisel kusurun iç içe olması nedeniyle meydana gelen zararda, zararın tazminine yönelik olarak idare aleyhine idari yargıda dava açılması gerekliliği ortaya çıkmaktadır (Kasapoğlu Turhan, 2013: 119). 
Mahkemenin vermiş olduğu karara ilişkin metin incelendiğinde, 2007 tarihinde hastane acil servisinde sargı bezi kalmaması hakkındaki soruşturmada uyarma cezası alan davacının olay anında hastanede olmadığı ve asıl sorumlunun başhekim olarak gösterildiği halde başhekime verilen uyarma cezasının kaldırıldığının görüldüğü belirtilmiştir (Sakarya 1. İdare Mahkemesi, 17.01.2011 T. 2010/474 E.; 2011/187 K). Psikolojik tacizin ortaya çıkması sürecinin her ne kadar tek bir olaya indirgenmesi güç olsa da, bu vakada bahsi geçen ve mahkeme karar metninde de yer verilen sargı bezi kalmaması soruşturması neticesinde yaşananlardan sürecin başlangıcına dair bir fikir edinebilmek mümkün olabilmektedir.

Aynı metinde dikkat çeken bir başka husus da acil serviste sargı bezi kalmamasına ilişkin açılan soruşturmaya dair raporun sonuç kısmıdır. Raporun sonuç kısmının incelenmesi ile hastane çalışanları arasında uzun süredir münakaşaların yaşandığı, kişilerin birbirleri hakkında tutanaklar tuttuğu ve başhekimler tarafindan davacının hastanede yaşanan olayların sorumlusu olarak cezalandırıldığının görüldüğü belirtilmiştir (Sakarya 1. İdare Mahkemesi, 17.01.2011 T. 2010/474 E.; 2011/187 K). Burada bahsi geçen husus neticesinde davacının dikey (hiyerarşik) psikolojik tacizin yanı sıra hastane çalışanları arasındaki yaşananlar neticesinde yatay psikolojik tacize de maruz kalmış olabileceği iddiası öne sürülebilir.

Psikolojik tacizin örgüt üzerindeki etkileri de yine mahkemenin vermiş olduğu karara ilişkin metin incelendiğinde görülebilmektedir. Mahkemenin karar metninde davacıya verilen disiplin cezalarının detaylı soruşturmalar yapılmadan sadece tutanaklara dayanılarak verildiği, asıl sorumluların tespitinde geniş soruşturmaların yapılması gerekliliği, tanık ifadelerinin alınması gerekliliği, yaşanan olaylarda davacının tek sorumlu gibi cezalar aldığı, 90 ve üzeri almış olduğu sicil notunun 2009 yılında 67 olarak verildiği ve aynı nedenlerle disiplin cezası almasına rağmen tekerrür hükmü uygulanmadığından davacının hakkını arama özgürlüğünü kullanamadığının görüldüğüne dikkat çekilmiştir (Sakarya 1. İdare Mahkemesi, 17.01.2011 T. 2010/474 E.; 2011/187 K). Dava metninde belirtilen hususlara dayanılarak, idarenin olaylardaki ve soruşturma süreçlerindeki tutumunun oldukça dikkat çekici olduğu söylenebilir. Psikolojik tacizin örgüt üzerindeki etkileri açısından değerlendirildiğinde, idarenin olaylara karşı tutumunun çalışanlar arasında bazı huzursuzluklara yol açabilme ihtimalinin bulunduğu ve bu hususun çalışanların verimine olumsuz bazı etkilerinin olabileceği ihtimal dahilindedir. Nitekim tüm bu yaşanan süreçlerin de mağdurun üzerinde çeşitli psikolojik etkilere sebep olabileceği yadsınamaz bir gerçeklik olarak kabul edilmesi gerekmektedir.

Yapılan yargılama sonucunda mahkeme davacıyı haklı bulmuş ve kararını şu şekilde belirtmiştir:

"Bu durumda, davalı idarenin disiplin cezaları ve geçici görevlendirmeler ile davacının kişilik haklarının ve manevi bütünlüğünü zarara uğrattığı sonucuna varıldığından davalı idare tarafindan davaciya takdiren 5.000.- TL manevi tazminat ödenmesi gerektiği sonucuna varılmıştır." (Sakarya 1. İdare Mahkemesi, 17.01.2011 T. 2010/474 E.; 2011/187 $\mathrm{K})$.

$\mathrm{Bu}$ vaka örneğinde, açılan dava neticesinde, psikolojik tacize dair mağdurun yaşamış olduğu tüm süreç resmi kayıtlara geçmiştir. Mahkeme tarafindan alınan karar neticesinde ise mağdurun psikolojik tacize uğradığı resmi olarak kabul edilmiştir. Kamu sektöründe yaşanan bu 
vaka gerek yaşanan süreç gerekse alınan karar neticesi ile benzer durumda olan mağdurlara yol göstermesi açısından oldukça önemlidir.

\section{2. Özel Sektörde Psikolojik Tacize Dair Vaka Örneği}

Yargıtay 9. Hukuk Dairesi'nde görülen bir davada davacı, yerel mahkeme olarak başvurduğu Asliye Hukuk (İş) Mahkemesi'nin reddettiği kıdem ve ihbar tazminatlarının işveren tarafından ödenmesine dair davayı temyize götürmüştür. Yapılan yargılama sonucunda Yargıtay, davacının maruz kaldığı uygulamaları mobbing olarak kabul etmiş ve yerel mahkemenin kıdem ve ihbar tazminatlarının işveren tarafından ödenmesini reddettiğine dair kararını bozmuştur (Yargitay 9. Hukuk Dairesi, 27.12.2012 T. 2010/35500 E.; 2012/44486 K).

Yerel mahkemenin karar metni özetinde davacının işvereninin hakaret ettiğini ispatlayamadığı, davacının çalışmış olduğu birim şartlarının ve koşullarının esaslı bir şekilde değiştirilmesinin söz konusu olmadığı, tadilatı tamamlanan satış bölümünde yeniden çalışabilecekken davacının bunu yapmadığı belirtilerek dava reddedilmiştir. (Yargıtay 9. Hukuk Dairesi, 27.12.2012 T. 2010/35500 E.; 2012/44486 K). Yerel mahkemenin bu kararına karş1, davacı tarafından kararın temyizine gidilmesinin ardından, Yargıtay'ın vermiş olduğu kararın gerekçesinde davacıya psikolojik tacize dair birtakım süreçlerin yaşatıldığına dikkat çekilmiştir.

Yargitay vermiş olduğu kararın gerekçesinde davacının satın alma bölümünde çalıştığı, yerel mahkemenin davacı tarafından iş akdinin haksız bir şekilde feshedildiği sonucuna ulaşılmasının dosya kapsamına uygun olmadığı, dosyadaki deliller neticesinde davacının bir tanıklık yapmasından dolayı çalıştığı işyerinde farklı muameleye maruz kaldığ neticesinde davacının savunmasının alındığı ve davacının yazılı muvafakati alınmadan çalıştığ yerin değiştirildiği hususlarını belirtmektedir (Yargıtay 9. Hukuk Dairesi, 27.12.2012 T. 2010/35500 E.; 2012/44486 K). Yargıtay kararının gerekçesi incelendiğinde örnek vakadaki mağdurun dikey (hiyerarşik) psikolojik tacize maruz kaldığı görülmektedir. Yargıtay'ın yerel mahkemenin aksine, davacının çalışmakta olduğu satın alma bölümünden alınarak satış bölümünde çalıştırılmak istenmesine dikkat çekmesi de önemli bir husus olarak karşımıza çıkmaktadır. Ayrıca gerekçede, psikolojik tacizin ortaya çıkması sürecinin de davacının yapmış olduğu bir tanıklığın ardından geliştiği vurgulanmıştır.

Yargıtay kararının gerekçesinde dikkat çeken bir başka husus ise davacının işyerindeki bir şoför ile aralarında bir ilişki olduğuna dair ispatlanamayan bir takım asılsız iddialara maruz bırakıldığının belirtilmesidir (Yargıtay 9. Hukuk Dairesi, 27.12.2012 T. 2010/35500 E.; 2012/44486 K). Bu durumun, mağdur üzerindeki psikolojik tacizin etkisini önemli ölçüde arttıracağı ve kişinin psikolojik sağlığında önemli sorunlara neden olabileceği yadsınamaz bir gerçeklik olarak karşımıza çıkmaktadır. İşyerindeki çıkartılan asılsız iddialar nedeniyle davacının yatay psikolojik tacize de uğramış olabilmesi ihtimal dahilindedir. Yaşanan tüm bu süreçler psikolojik tacizin örgüt üzerindeki etkileri bakımdan da oldukça önemlidir. Diğer çalışanların da ileride meydana gelebilecek olaylar karşısında tanıklık yapma gibi durumları olduğu takdirde, benzer süreçleri yaşayabilecekleri endişesini taşıyacakları aşikardır. Böyle bir ortamdaki çalışanların çalışma verimlerinin de bu tür hususlardan olumsuz yönde etkilenebileceği ihtimali yadsınamaz bir gerçekliktir. 
Yargıtay açılan bu davada, davacıya karşı yapılan tüm bu bahsi geçen uygulamaların "yıldırma (mobbing)" olarak kabul edilmesi gerektiğine, davacının iş akdini haklı olarak feshettiğine ve yerel mahkemenin davacının kıdem tazminatının hüküm altına alınmasını reddine yönelik kararının isabetsiz olduğuna karar vermiştir (Yargitay 9. Hukuk Dairesi, 27.12.2012 T. 2010/35500 E.; 2012/44486 K). Yargitay tarafindan alınan karar neticesinde mağdurun psikolojik tacize uğradığ 1 resmi olarak kabul edilmiştir. Kararda açıkça "yıldırma (mobbing)" ifadesine yer verilmesi de oldukça önemlidir. Zira bu ve benzeri yargı kararları ile özel sektörde yaşanan benzeri vakalarda mağdurlara izlemeleri gereken bir yol gösterilmiş ve mağdurların yargıya başvurarak haklarını koruyabileceklerine dair inançlarının daha da kuvvetlenmesine olanak sağlanmıştır.

\section{SONUÇ}

Psikolojik taciz özellikle son yıllarda yaygınlığını artıran, çoğu kurumda sıç̧a maruz kalınan ve varlığını sinsice devam ettiren bir kavramdır. Psikolojik taciz; psikolojik yıldırma, psikolojik şiddet ve mobbing gibi farklı ifadeler ile de adlandırılabilmektedir. Bu kavram, insan onuruna aykırı bir davranış olarak da ele alınmalıdır. Psikolojik tacize uğrayan kişiler, iş yaşamında yaşadıkları bu baskının olumsuz etkilerini özel hayatlarında da yaşamaktadır. Bu nedenle konuya dair yasal düzenlemelerin, eğitimin ve farkındalık çalışmalarının etkin olarak işletilmesi; bilinç seviyesinin artırılması gerekmektedir.

Psikolojik tacizin sebep olduğu cinnet, cinayet ve intiharlar bu konunun ciddiyetini ve ne derece önem arz ettiğini de gözler önüne sermektedir. Kamu sektöründe ve özel sektörde faaliyet gösteren tüm kurumlar, bu konuyla mücadele etmeli ve psikolojik tacize mahal vermemek adına bilinçli ve duyarlı olmalıdırlar. Kurumların yanı sıra kişilerinde bu hususa karşı bilinçli ve duyarlı olmaları gerekmektedir. Bireysel olarak, çalışanların öncelikle sahip oldukları hakları ve gerektiği zaman başvurabilecekleri mercileri bilmeleri oldukça önem arz etmektedir. Genel olarak hem özel sektörde hem kamu sektöründe çalışanlar için psikolojik tacize maruz kalmaları durumunda benzer haklar ve şikayet mercileri bulunmasına karşın, bu hususta bazı küçük farklılıkların olabileceği de göz önünde bulundurulmalıdır.

Çalışma hayatında gerek amirlerden gerekse benzer kademede çalışan personellerden bazı olumsuz tutum ve davranışlar zaman zaman görülebilmektedir. Çok ender olsa da astlar da üstlerine karşı bazen olumsuz tutumlara sahip olabilir. Bu tür durumlarda yaşanılan tutum ve davranışların değerlendirilmesi gerekir. Eğer fiziksel şiddet gibi hukuki olarak suç teşkil edecek bir durum varsa ya da olumsuz tutumlar sistematik bir şekilde devam etmiyorsa yaşanılan durumun psikolojik taciz olarak nitelendirilme imkanı bulunmamaktadır. Nitekim Yargitay tarafından alınan kararda da "mobbingde, işçiye karşı taciz psikolojik olmalı, işçinin özgüvenini ve özsaygısını kaybettirmeli, sistematik olarak tekrarlanmalı, uzun bir zamandan beri devam ediyor olmalı ve en önemlisi işçinin buna karşı silahı olmamalı, olsa bile kullanamamalıdır" (Yargitay 9. Hukuk Dairesi, 04.04.2016 T. 2014/37332 E.; 2016/8155 K) denilerek tacizin psikolojik ve sistematik olması gerekliliği belirtilmiştir.

Gerek basında çıkan haberler gerekse yargıya intikal etmiş psikolojik tacize dair vakalar incelendiğinde, genellikle psikolojik tacizin başlangıcının sebepsiz olmadığ 1 görülebilmektedir. Belirli bir olayın tetiklediği bu sürecin gelişim aşamalarının da pek çok vakada benzer olduğuna 
dikkat edilmelidir. Çalışma içerisinde verilmiş olan kamu ve özel sektördeki vaka örneklerinde de görülebileceği üzere mağdurlar, sistematik bir şekilde baskı altına alınmaya çalışılmaktadır. $\mathrm{Bu}$ baskı gerek kişilere soruşturmaların açılması ve savunmalarının istenmesi ile gerekse çalışmakta oldukları birim ya da işyerlerinin rızaları olmadan değiştirilmesi ile gerçekleşebilmektedir. Pek çok vakada kişilerin üstlerinden veya bağlı oldukları amirlerinden dikey (hiyerarşik) psikolojik taciz gördükleri anlaşılmaktadır. Ancak sürecin ilerlemesi ile birlikte benzer kademelerde çalışanlardan da yatay psikolojik taciz görülebilmektedir. Yatay psikolojik tacizin başlamasında mağdura kurum içerisinde açılan soruşturmaların, tutulan tutanakların veya baskı amacı ile yapılan haksız isnatların diğer çalışanlar üzerinde oluşturduğu olumsuz izlenim ve etkilerin neden olduğu söylenebilir.

Çalışma içerisinde verilen ve çalışma içerisinde verilmeyip bu süreç içerisinde incelenmiş olan örnek vakaların pek çoğunda mağdurların yargı yolu ile vermiş oldukları mücadelelerde başarılı sonuçlar elde ettikleri görülmektedir. Alınan başarılı sonuçlar, psikolojik tacize maruz kalan ve bu husustaki mücadelesini yargı yolunu kullanarak vermeye çalışan mağdurlar için hem izlemeleri gereken örnek bir yol oluşturmakta hem de onlar için bir cesaret ve motivasyon kaynağ olarak büyük bir önem arz etmektedir. Tabi ki başarılı sonuç alınamayan veya intihar gibi hiç istenmeyen sonuçlara giden süreçleri bulunan bazı vakaların varlığı da bulunmaktadır. Ancak psikolojik tacize maruz kalmış kişilerin cesaret ve motivasyonlarının sürekli yüksek kalması için mutlaka her daim başarılı sonuçların göz önüne alınması oldukça önemli bir gerekliliktir. Bu hususta çeşitli sivil toplum örgütlerinin kişilere sağlamış olduğu manevi ve hukuki destek de kurumsal mücadelenin önemi açısından dikkat çekici bir başka noktadır.

Psikolojik tacizin bir başka boyutu da sürecin örgüt üzerindeki olumsuz etkileridir. Günümüzde hala en önemli üretim faktörü olan insanın verimli ve etkin bir çalışma ortaya çıkarabilmesi, sağlıklı ve güvenilir bir çalışma ortamında mümkündür. Ancak yıpranan örgütsel bağl11ı, zedelenen kurumsal yapı, zayıflayan ve kopan iletişim ağları ve buna benzer psikolojik taciz sonuçları nedeniyle, çalışma ortamından verim elde edilmesi oldukça güçleşebilmektedir.

Gerek kamu gerekse özel sektörde psikolojik taciz, bütün çalışma ortamlarında personel ya da işveren kaynaklı olarak varlığını sürdüren, bireye ve kuruma zarar veren; çalışanların ve kurumun başarısı, bütünlüğü ve huzuru için imha edilmesi gereken bir olgudur. Bireyin bilinci, doğru bir tutumda bulunuşu ve yönetimin olaya yaklaşımı ile seyri değişebilecek ya da ortadan kalkabilecek bu olgu için de gerek bireysel gerekse kurumsal mücadelede bulunmak oldukça önem arz etmektedir.

\section{KAYNAKÇA}

Akyüz, A. M. (2015). Üniversite Öğrencilerine Yönelik Mobbing. Sosyal Bilimler Dergisi, 8(1), $2-42$.

Altuntaş, C. (2010). Mobbing Kavramı ve Örnekleri Üzerine Uygulamalı Bir Çalışma. Journal of Yaşar University, 5(18), 2995-3015.

Aslım, O. (2017, 3 Şubat). Mobbing'e Uğrayan Çalışan Ne Yapmalı?. İkblog. https://www.kariyer.net/ik-blog/mobbinge-ugrayan-calisan-ne-yapmali/ 
Aşkın, E. Ö. \& Aşkın, U. (2018). Çalışma Yaşamında Kadına Yönelik Mobbing: Bankacılık Sektöründe Bir Araştırma. Gümüşhane Üniversitesi Sosyal Bilimler Enstitüsü Elektronik Dergisi, 9(24), 255-282.

Başhemşire mobbing davasını kazand1. (2011, 23 Mart). Cnn Türk. https://www.cnnturk.com/2011/turkiye/03/23/bashemsire.mobbing.davasini.kazandi/6109 32.0/iinde.html

Bireysel destek. (t.y.). Mobing ile Mücadele Derneği. https://www.mobbing.org.tr/bireyseldestek/

Cevher, E. \& Öztürk, U. C. (2015). İş Yaşamında Kadınların Kadınlara Yaptığı Mobbing Üzerine Bir Araştırma. Insan ve Toplum Bilimleri Araştırmaları Dergisi, 4(4), 860-876.

Çekin, A. (2014). Çalışma Hayatında İnsan Onuruna Karşı Psikolojik Bir Şiddet Örneği: Mobbing. Kastamonu Üniversitesi İktisadi ve İdari Bilimler Fakültesi Dergisi, 3(1), 5-22.

Erdem, T. (2014). Mobbing ve Mobbing ile Mücadele Yöntemleri. Türk Kütüphaneciliği, 28(4), $622-628$

Gedikkaya, M. T. (2019). Kamuda Psikolojik Taciz (Mobbing) ile Mücadele Politikasının Değerlendirilmesi: Psikolojik Taciz Genelgesi Örneği. Gaziantep Üniversitesi İktisadi ve İdari Bilimler Fakültesi Dergisi, 1(2), 53-70.

Hüseyinli, N. \& Aslan Atabay, H. (2017). Psikolojik Tacizin İçtihatlar Işı̆̆ında Uygulamadaki Yeri. İnönü Üniversitesi Hukuk Fakültesi Dergisi, 8(2), 603-636.

İdiğ Çamuroğlu, M. \& Minibas Poussard, J. (2017). Psikolojik Taciz: Türkiye Genelinde Bir Araştırma. Finans Politik \& Ekonomik Yorumlar, 54(624), 53-68.

Karakaş, S. A. \& Okanl1, A. (2013). Hemşirelik ve Mobbing. Gümüşhane Üniversitesi Sağllk Bilimleri Dergisi, 2(4), 562-576.

Kasapoğlu Turhan, M. (2013). Kamu Görevlileri Bakımından İşyerinde Psikolojik Taciz (Mobbing) ve Hukuki Korunma Yolları. Türkiye Barolar Birliği Dergisi, (105), 89-128.

Maraş Büken, S. (2019, 9 Ocak). Kamu Görevlisine Mobbing Uygulanması. Büken Hukuk \& Danışmanlık. https://buken.av.tr/kamu-gorevlisi-mobbing-memur/

Mizrahi, R. (2013). Çalışma Hayatında Mobbing ile Mücadele Yöntemleri. Sosyal ve Beşeri Bilimler Dergisi, 5(2), 443-452.

Özçelik Sözer, B. (2017, 3 Kasım). Mobbing En Çok Özel Sektörü Vuruyor. Hürriyet. https://www.hurriyet.com.tr/ik-yeni-ekonomi/mobbing-en-cok-ozel-sektoru-vuruyor40633353

Özen, S. (2007). İşyerinde Psikolojik Şiddet ve Nedenleri. Isss, Güç Endüstri İlişkileri ve İnsan Kaynakları Dergisi, 9(3), 1-24.

Öztürk, M. \& Şahbudak, E. (2017). İşyerinde Psikolojik Taciz (Mobbing) ve İş Doyumu: Cumhuriyet Üniversitesindeki Araştırma Görevlileri Üzerine Bir Çalışma. Sosyoloji Araştırmaları Dergisi, 20(2), 200-228. 


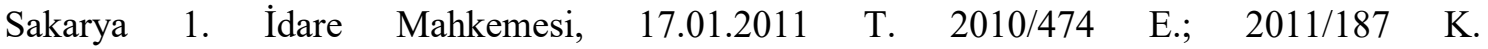
https://www.kararara.com/forum/viewtopic.php?t=15736

Seçkin Halaç, D. \& Güloğlu, C. (2019). İşyerinde Psikolojik Yıldırma Olgusunun Çalışan Verimliliği Üzerine Etkisi: MOSB'de Bir Saha Araştırması. Yönetim ve Ekonomi: Celal Bayar Üniversitesi İktisadi ve İdari Bilimler Fakültesi Dergisi, 26(1), 157-180.

Şahin, S. (2015). Yeni Bir Yaklaşım: İş Sağlığı ve Güvenliği’nde Mobbing Faktörünün Önemi ve Etkisi. Akademik Sosyal Araştırmalar Dergisi, (9), 489-505.

Şikayet ve başvuru yolları (t.y.). Mobbing ile Mücadele Derneği. https://www.mobbing.org.tr/sikayet-ve-basvuru-yollari/

Şimşek, S. \& Doğan, F. (2019). Otel Çalışanlarının Psikososyal Risk Etmenleri Açısından Mobbinge Maruz Kalmalarının Araştırılması. İsg Akademik, 1(1), 59-67.

Tetik, S. (2010). Mobbing Kavramı: Birey ve Örgütler Açısından Önemi. Karamanoğlu Mehmetbey Üniversitesi Sosyal ve Ekonomik Araştırmalar Dergisi, (1), 81-89.

Tınaz, P. (2006). Mobbing: İşyerinde Psikolojik Taciz. Çalışma ve Toplum, (10), 11-22.

Yapışlar, E. E. (t.y.). Mobbing (İ̧̧ Yerinde Psikolojik Taciz) Kavramı ve İ̧̧ Hukuk Düzleminde Değerlendirilmesi. KYK Legal. http://kyklegal.com/mobbing-is-yerinde-psikolojik-tacizkavrami-ve-ic-hukuk-duzleminde-degerlendirilmesi/

Yargitay 9. Hukuk Dairesi, 27.12.2012 T. 2010/35500 E.; 2012/44486 K. https://karararama.yargitay.gov.tr/YargitayBilgiBankasiIstemciWeb/

Yargitay 9. Hukuk Dairesi, 04.04.2016 T. 2014/37332 $\quad$ E.; 2016/8155 K. https://karararama.yargitay.gov.tr/YargitayBilgiBankasiIstemciWeb/

Yorulmaz, M. (2019). Türkiye'de Mobbing Konusunda Yapılan Tez Çalışmaları: Meta Analizi. Uluslararası Sosyal Araştırmalar Dergisi, 12(62), 1636-1644.

Yöney, E. Y. \& Kılınç, E. (2020). Bankacılık Sektöründe Psikolojik Yıldırmanın Çalışanların İş ve Yaşam Tatmini Üzerindeki Etkisinin İncelenmesi. İktisadi İdari ve Siyasal Araştırmalar Dergisi, 5(11), 34-52.

Yücetürk, E. E. (2012). İşyerlerindeki Yıldırma Eylemlerini Önlenmede Sendikaların Rolü: Nitel Bir Araştırma. Çalışma ve Toplum, (35) 41-72. 